\title{
The Caries-Preventive Effect of Chlorhexidine Varnish in Children and Adolescents: A Systematic Review
}

\author{
P. James C. Parnell H. Whelton \\ Oral Health Services Research Centre, Cork University Dental School and Hospital, Cork, Ireland
}

\section{Key Words}

Antimicrobials $\cdot$ Caries $\cdot$ Chlorhexidine $\cdot$ Review

\begin{abstract}
Aims: Our purpose was to systematically review the literature on the effectiveness of chlorhexidine varnish for preventing dental caries in children and adolescents and to determine its effectiveness compared to fluoride varnish. Methods: MEDLINE, EMBASE and the Cochrane Library were searched through December 2009 to identify relevant randomised trials with blind outcome assessment and a minimum duration of 1 year. The search was later updated in MEDLINE and the Cochrane Library to March 19th, 2010. Risk of bias of the included trials was assessed. The primary outcome was the caries increment. Results: Twelve trials met the inclusion criteria for the review. There was considerable variation between trials in the concentration and frequency of application of the chlorhexidine varnish, in baseline caries levels and in background exposure to fluoride. Six parallelgroup trials reported no statistically significant difference in caries increment in permanent teeth with the application of chlorhexidine varnish compared to placebo or no treatment. The results of 4 split-mouth trials were conflicting: 2 trials found no significant difference in caries increment and 2 reported statistically significant results in favour of chlorhexi-
\end{abstract}

dine varnish. One trial of the effect of chlorhexidine varnish in primary teeth demonstrated a statistically significant reduction in caries increment. The results of 1 trial comparing chlorhexidine varnish with fluoride varnish for preventing caries in adolescents were equivocal. Conclusion: Evidence regarding the effectiveness of chlorhexidine varnish for preventing caries is inconclusive. Further well-conducted randomised trials are required before chlorhexidine varnish can be recommended for caries prevention.

Copyright $\odot 2010$ S. Karger AG, Basel

Although the prevalence and severity of dental caries has declined in many developed countries in recent decades, the disease is still a major public health problem in industrialised countries and is an emerging public health problem in developing countries, as a consequence of increased consumption of sugars, inadequate exposure to fluoride and limited access to dental care [Petersen, 2003].

There is a large body of evidence to support the use of topical fluorides (varnish, gel, toothpaste, mouthrinse) [Marinho et al., 2002a; Marinho et al., 2002b; Marinho et al., 2003a; Marinho et al., 2003b] and fissure sealants [Mejàre et al., 2003; Ahovuo-Saloranta et al., 2008] for caries prevention. Mutans streptococci (MS) have been shown to play a major role in the initiation of the caries

\section{KARGER}

Fax +4161306 1234 E-Mail karger@karger.ch www.karger.com
(C) 2010 S. Karger AG, Basel

0008-6568/10/0444-0333\$26.00/0

Accessible online at:

www.karger.com/cre
Patrice James

Oral Health Services Research Centre

Cork University Dental School and Hospital

Wilton, Cork (Ireland)

Tel. +353 21490 1210, Fax +353 21454 5391, E-Mail p.james@ ucc.ie 
process [van Houte, 1980; Loesche, 1986], and the use of antimicrobials, as an alternative to or in combination with fluoride, has also been explored.

Chlorhexidine is an antimicrobial agent that is particularly effective in reducing the levels of MS in saliva and dental plaque [Emilson, 1981; Schaeken et al., 1989; Schaeken et al., 1991; Emilson, 1994]. Its effectiveness is attributed to its substantivity (i.e. its ability to maintain therapeutic activity for a prolonged period of time), which is facilitated by its adsorbtion onto tooth surfaces, pellicle, plaque and mucous membranes [Rölla et al., 1971; Bonesvoll et al., 1974]. Chlorhexidine has been studied extensively both as an antiplaque and antigingivitis agent and for its potential to prevent and control dental caries. It is available in a variety of different formulations (i.e. mouthrinse, gel, varnish, toothpaste) and concentrations. Chlorhexidine varnish was developed to prolong the contact of the chlorhexidine with the teeth and to provide sustained release of the antimicrobial agent for increased effectiveness [Balanyk and Sandham, 1985].

Studies published in the 1970s and 1980s evaluating the caries-preventive effect of chlorhexidine gel, rinse and toothpaste reported generally positive results [van Rijkom et al., 1996]. However, the results of subsequent trials, mainly evaluating chlorhexidine varnish, conducted in a variety of locations worldwide and published by many different research groups, have produced conflicting results. The systematic review by Twetman [2004] included 16 trials published between 1995 and 2003. Due to the conflicting results of the trials, evidence for the effectiveness of chlorhexidine varnish was rated as inconclusive. Based on the results of 10 trials, 8 of which had featured in the Twetman review, Zhang et al. [2006a] concluded that chlorhexidine varnish had a moderate caries-preventive effect when applied at intervals of 3-4 months. The authors of this systematic review added that there was no evidence for effectiveness with longer intervals of application.

Both reviews included randomised and controlled clinical trials involving children and adolescents, but neither review presented an assessment of the methodological quality of the included trials. In addition, the cariespreventive effect of chlorhexidine in primary teeth was not investigated. Randomised trials are considered to provide the best evidence of effect because the randomisation of participants to intervention and control groups minimises selection bias. The aim of this review is to summarise the evidence of the effectiveness of chlorhexidine varnish at preventing caries in the permanent and primary teeth of children and adolescents compared to placebo or no treatment, using data from randomised controlled trials only. A secondary aim is to summarise the evidence of the caries-preventive effectiveness of chlorhexidine varnish compared to fluoride varnish.

\section{Materials and Methods}

A search strategy was developed around the terms 'chlorhexidine varnish' and 'dental caries' and run in MEDLINE, EMBASE and the Cochrane Central Register of Controlled Trials through December 2009. The search was later updated in MEDLINE and the Central Register of Controlled Trials to March 19th, 2010. The search results were limited to include only trials on humans, in English and limited to individuals aged $\leq 18$ years. Six hundred and ninety-eight non-duplicate records were obtained. Previously published systematic reviews were examined for their included trials and reference lists in these reviews were searched, but no additional relevant trials were identified.

Inclusion criteria for the review were decided a priori and applied independently by 2 authors (P.J. and C.P.). Randomised or quasi-randomised controlled trials with blind outcome assessment and a minimum duration of 1 year comparing chlorhexidine varnish to placebo, no treatment or fluoride varnish, in children and adolescents aged 18 years or younger, were included in the review. A decision was made to include split-mouth as well as parallel-group trials for the main review outcome (chlorhexidine varnish versus placebo or no treatment) but to analyse them separately. Split-mouth trials are considered problematic when evaluating the effect of chlorhexidine varnish because of the potential for a carry-over effect from the test to the control side. However, a systematic review which looked at the effect of different formulations of chlorhexidine at reducing the levels of MS in the mouth found no difference in the decrease in MS levels observed in the split-mouth trials compared to other studies with control groups [Ribeiro et al., 2007], which would suggest a negligible impact if carry-over had occurred. It has also been suggested that the amount of chlorhexidine that is released from varnish is too low to be effective on other sites of the dentition [Zhang et al., 2006a]. For the comparison between chlorhexidine varnish and fluoride varnish, only parallel-group trials were included, as a carry-over effect for fluoride varnish in split-mouth trials cannot be ruled out [Marinho et al., 2002a]. Trials where chlorhexidine varnish explicitly formed part of a combined intervention with other preventive methods were excluded.

The primary outcome measure was the caries increment determined using the decayed missing and filled surface (DMFS/ $\mathrm{dmfs}$ ) index. Only trials where caries was assessed by visual/visual-tactile or radiographic methods were included. Side effects such as discoloration of teeth or oral allergic reactions, and acceptability of treatment measured by dropouts or reports of poor taste were considered as secondary outcomes.

Titles and abstracts of the 698 deduplicated records were screened and 22 were considered potentially relevant and examined in full. Additional data were sought from the authors of 3 trials regarding blind outcome assessment [Madlena et al., 2000; Jenatschke et al., 2001; Rodrigues et al., 2008] and were received for 2 [Jenatschke et al., 2001; Rodrigues et al., 2008], which per- 
Table 1. Parallel-group trials comparing chlorhexidine varnish to placebo/no treatment/fluoride varnish

\begin{tabular}{|c|c|c|c|c|c|c|c|c|c|c|c|c|c|}
\hline Trial & $\begin{array}{l}\text { Age } \\
\text { years }\end{array}$ & $\begin{array}{l}\text { Inter- } \\
\text { ven- } \\
\text { tion }\end{array}$ & $\begin{array}{l}\text { Com- } \\
\text { pari- } \\
\text { son }\end{array}$ & $\begin{array}{l}\text { Application } \\
\text { frequency }\end{array}$ & $\mathrm{n}$ & $\begin{array}{l}\text { Drop- } \\
\text { outs } \\
\%\end{array}$ & $\begin{array}{l}\text { Trial } \\
\text { duration } \\
\text { years }\end{array}$ & $\begin{array}{l}\text { Tooth } \\
\text { type/ } \\
\text { surface }\end{array}$ & $\begin{array}{l}\text { Mean } \\
\text { DMFS } \\
\text { baseline }\end{array}$ & $\begin{array}{l}\text { Exposure to } \\
\text { fluoride }\end{array}$ & $\begin{array}{l}\triangle \mathrm{DMFS} \\
\mathrm{CHX} / \\
\text { comparison }\end{array}$ & $\begin{array}{l}\text { Statistical } \\
\text { significance } \\
\text { (p value) }\end{array}$ & $\begin{array}{l}\text { Risk } \\
\text { of } \\
\text { bias }\end{array}$ \\
\hline \multicolumn{14}{|c|}{ Permanent teeth } \\
\hline $\begin{array}{l}\text { Baca } \\
{[2003]} \\
(\mathrm{RCT})\end{array}$ & $6-7$ & $\begin{array}{l}\text { CHX 1\% } \\
+ \text { thymol } \\
1 \%\end{array}$ & no tx & $3 / 12$ & 127 & 45 & $\begin{array}{l}\text { evaluated } \\
3 \text { years } \\
\text { after end } \\
2 \text {-year trial }\end{array}$ & FPM/all & $0.23(\mathrm{D})$ & FTP assumed & $\begin{array}{l}\text { D: } \\
3.03 / 2.86\end{array}$ & $\begin{array}{l}\text { NS } \\
(p=0.877)\end{array}$ & high \\
\hline $\begin{array}{l}\text { Ersin } \\
{[2008]} \\
(\mathrm{RCT})\end{array}$ & $11-13$ & $\begin{array}{l}\text { CHX 1\% } \\
+ \text { thymol } \\
1 \%\end{array}$ & DHE & $3 / 12$ & 149 & 15.4 & 2 & all/all & 0 & $\begin{array}{l}\text { FTP } \\
\text { F water } \\
0.3-0.4 \mathrm{ppm}\end{array}$ & $\begin{array}{l}\text { D: } \\
0.95 / 1.05\end{array}$ & $\begin{array}{l}\text { NS } \\
(p>0.05)\end{array}$ & low \\
\hline \multirow[t]{2}{*}{$\begin{array}{l}\text { Forgie } \\
{[2000]} \\
(\mathrm{RCT})\end{array}$} & \multirow[t]{2}{*}{$11-13$} & \multirow[t]{2}{*}{$\begin{array}{l}\text { CHX } \\
10 \%\end{array}$} & \multirow[t]{2}{*}{$\begin{array}{l}\text { pla- } \\
\text { cebo }\end{array}$} & \multirow{2}{*}{$\begin{array}{l}6-12 \\
\text { applications } \\
\text { depending } \\
\text { on MS levels }\end{array}$} & \multirow{2}{*}{592} & \multirow[t]{2}{*}{16.2} & \multirow[t]{2}{*}{3} & \multirow[t]{2}{*}{ all/all } & \multirow[t]{2}{*}{$4.11(\mathrm{D})$} & \multirow[t]{2}{*}{ FTP assumed } & $\begin{array}{l}\text { E+D clinical } \\
+\mathrm{B} / \mathrm{W}: \\
11.03 / 10.24\end{array}$ & NS & \multirow[t]{2}{*}{$\begin{array}{l}\text { un- } \\
\text { clear }\end{array}$} \\
\hline & & & & & & & & & & & D: $6.83 / 6.39$ & NS & \\
\hline $\begin{array}{l}\text { De Soet } \\
{[2002]} \\
\text { (RCT) }\end{array}$ & $13-14$ & $\begin{array}{l}\text { CHX } \\
40 \%\end{array}$ & $\begin{array}{l}\text { pla- } \\
\text { cebo }\end{array}$ & $6 / 12$ & 238 & 18.5 & 2.5 & all/all & 3.93 & $\begin{array}{l}\text { FTP use } \\
\text { uncommon }\end{array}$ & $\begin{array}{l}E+D: \\
2.07 / 1.68\end{array}$ & NS & $\begin{array}{l}\text { un- } \\
\text { clear }\end{array}$ \\
\hline \multirow{2}{*}{$\begin{array}{l}\text { Fennis-le } \\
{[1998]} \\
(\mathrm{RCT})\end{array}$} & \multirow[t]{2}{*}{6 and 12} & \multirow[t]{2}{*}{$\begin{array}{l}\mathrm{CHX} \\
40 \%\end{array}$} & \multirow[t]{2}{*}{$\begin{array}{l}\text { pla- } \\
\text { cebo }\end{array}$} & \multirow[t]{2}{*}{$6 / 12$} & \multirow[t]{2}{*}{332} & \multirow[t]{2}{*}{5} & \multirow[t]{2}{*}{3} & \multirow{2}{*}{$\begin{array}{l}\text { FPM } \\
\text { SPM/ } \\
\text { Occ. }\end{array}$} & \multirow{2}{*}{$\begin{array}{l}1.95 \mathrm{dmfs} \\
\text { (age 6) } 1.0 \\
\text { (age 12) }\end{array}$} & \multirow{2}{*}{$\begin{array}{l}\text { FTP assumed } \\
\text { topical F } \\
6 / 12\end{array}$} & $\begin{array}{l}E+D: \\
1.4 / 1.5\end{array}$ & NS & \multirow[t]{2}{*}{$\begin{array}{l}\text { un- } \\
\text { clear }\end{array}$} \\
\hline & & & & & & & & & & & D: $0.6 / 0.6$ & NS & \\
\hline $\begin{array}{l}\text { Jenatschke } \\
{[2001]} \\
(\mathrm{RCT})\end{array}$ & 11-18 & $\begin{array}{l}\text { CHX } \\
40 \%\end{array}$ & $\begin{array}{l}\text { pla- } \\
\text { cebo }\end{array}$ & $2 / 12$ & 33 & 0 & $\begin{array}{l}\text { median } \\
21 \\
\text { months }\end{array}$ & all/all & $9.25(\mathrm{D})$ & $\begin{array}{l}\text { FTP assumed } \\
\text { FMR daily } \\
\text { F gel weekly }\end{array}$ & D: $3.9 / 6.3$ & NS & high \\
\hline $\begin{array}{l}\text { Petersson } \\
{[2000]} \\
(\mathrm{RCT})\end{array}$ & $13-14$ & $\begin{array}{l}\text { CHX 1\% } \\
+ \text { thymol } \\
1 \%\end{array}$ & $\begin{array}{l}\text { FV } \\
0.1 \%\end{array}$ & $3 / 12$ & 180 & 8 & 3 & $\begin{array}{l}\text { canine- } \\
\text { 2nd molar/ } \\
\text { Approx. }\end{array}$ & 2.35 & $\begin{array}{l}\text { FTP } \\
\text { FV at } \\
\text { least once/ } \\
\text { year }\end{array}$ & $\begin{array}{l}\mathrm{E}+\mathrm{D} \\
\mathrm{B} / \mathrm{W}: \\
3.08 / 2.81\end{array}$ & NS & $\begin{array}{l}\text { un- } \\
\text { clear }\end{array}$ \\
\hline $\begin{array}{l}\text { Primary tee } \\
\text { Du [2006] } \\
\text { (RCT) }\end{array}$ & $4-5$ & $\begin{array}{l}\text { CHX } \\
40 \%\end{array}$ & $\begin{array}{l}\text { pla- } \\
\text { cebo }\end{array}$ & $6 / 12$ & 334 & 13 & 2 & $\begin{array}{l}\text { primary } \\
\text { molars/all }\end{array}$ & $\begin{array}{l}2.7(\mathrm{dmfs} \\
\text { molar })\end{array}$ & $\begin{array}{l}\text { F water } 0.1- \\
0.3 \text { ppm }\end{array}$ & $\begin{array}{l}\text { D: } 1.0 / 1.6 \\
\text { PF } 37.3 \%\end{array}$ & $\begin{array}{l}S \\
(p=0.036)\end{array}$ & low \\
\hline
\end{tabular}

$\mathrm{n}=$ Number of participants at baseline; $\mathrm{CHX}=$ chlorhexidine; $\mathrm{RCT}=$ randomised controlled trial; no tx $=$ no treatment; $\mathrm{DHE}=\mathrm{dental}$ health education; FPM = first permanent molar; SPM = second permanent molar; Occ. = occlusal surface; Approx. = approximal surface; $\mathrm{D}=$ dentine; E+D = enamel + dentine; $\mathrm{S}=$ statistically significant; NS = not statistically significant; F = fluoride; FMR = fluoride mouthrinse; FTP = fluoride toothpaste; FV = fluoride varnish; $\mathrm{B} / \mathrm{W}=$ bitewing radiographs; $\mathrm{PF}=$ prevented fraction.

mitted their inclusion in the review. In all, 12 trials met the inclusion criteria [Bratthall et al., 1995; Fennis-le et al., 1998; Forgie et al., 2000; Petersson et al., 2000; Jenatschke et al., 2001; De Soet et al., 2002; Baca et al., 2003; Haukali and Poulsen, 2003; Du et al., 2006; Zhang et al., 2006b; Ersin et al., 2008; Rodrigues et al., 2008] and 10 were excluded [Ogaard et al., 1997; Twetman and Petersson, 1999; Madlena et al., 2000; Splieth et al., 2000; Araujo et al., 2002; Baca et al., 2002; Baca et al., 2004; Skold-Larsson et al., 2004; Plotzitza et al., 2005; De Amorim et al., 2008]. In one of the included trials [Ersin et al., 2008], the control group received dental health education every 3 months. It was considered acceptable to include this trial in the review because this group was the intended control group and dental health education alone has not been shown to be effective in reducing caries [Kay and Locker, 1996; Vanobbergen et al., 2004]. Data were extracted from the included trials by 1 author (P.J.) using a specially developed data extraction form and checked by another author (C.P.).

\section{Assessment of Risk of Bias in Included Trials}

Risk of bias of the included trials was assessed independently by 2 authors (P.J. and C.P.) using the 'risk of bias' assessment tool described in the Cochrane Handbook for Systematic Reviews of Interventions Version 5.0.2 [Higgins and Deeks, 2009]. Any areas of disagreement were resolved by discussion. The overall assessments of risk of bias for each trial as 'high', 'low' and 'unclear' are listed in tables 1 and 2 .

\section{Data Analysis}

It was envisaged that the results of the included trials would be presented graphically in a forest plot and that statistical heteroge- 
Table 2. Split-mouth trials comparing chlorhexidine varnish to placebo/no treatment

\begin{tabular}{|c|c|c|c|c|c|c|c|c|c|c|c|c|}
\hline Trial & $\begin{array}{l}\text { Age } \\
\text { years }\end{array}$ & $\begin{array}{l}\text { Inter- } \\
\text { vention }\end{array}$ & $\begin{array}{l}\text { Com- } \\
\text { parison }\end{array}$ & $\begin{array}{l}\text { Application } \\
\text { frequency }\end{array}$ & $\mathrm{n}$ & $\begin{array}{l}\text { Drop- } \\
\text { outs } \\
\%\end{array}$ & $\begin{array}{l}\text { Trial } \\
\text { duration } \\
\text { years }\end{array}$ & $\begin{array}{l}\text { Tooth type/ } \\
\text { surface }\end{array}$ & $\begin{array}{l}\text { Mean DMFS } \\
\text { at baseline }\end{array}$ & $\begin{array}{l}\text { Exposure } \\
\text { to } \mathrm{F}\end{array}$ & $\begin{array}{l}\text { Statistical } \\
\text { significance } \\
\text { ( } \mathrm{p} \text { value) }\end{array}$ & $\begin{array}{l}\text { Risk } \\
\text { of } \\
\text { bias }\end{array}$ \\
\hline \multirow{2}{*}{$\begin{array}{l}\text { Bratthall } \\
\text { [1995] } \\
\text { (RCT) }\end{array}$} & \multirow[t]{2}{*}{$\begin{array}{l}7-8 \text { and } \\
12-13\end{array}$} & \multirow[t]{2}{*}{$\begin{array}{l}\text { CHX 1\%+ } \\
\text { thymol 1\% }\end{array}$} & \multirow[t]{2}{*}{ no tx } & \multirow[t]{2}{*}{$4 / 12$} & \multirow[t]{2}{*}{502} & \multirow[t]{2}{*}{15.7} & \multirow[t]{2}{*}{2} & \multirow[t]{2}{*}{$\begin{array}{l}\text { FPM and } \\
\text { SPM/Occ. }\end{array}$} & $\begin{array}{l}0.18 \text { and } \\
3.82\end{array}$ & $\begin{array}{l}\text { not } \\
\text { reported }\end{array}$ & $\begin{array}{l}\text { D: age groups } \\
\text { pooled in analysis }\end{array}$ & \multirow[t]{2}{*}{ low } \\
\hline & & & & & & & & & $\begin{array}{l}\text { test and control } \\
\text { teeth caries-free }\end{array}$ & & $\mathrm{S}(\mathrm{p}<0.001)$ & \\
\hline $\begin{array}{l}\text { Haukali } \\
\text { [2003] } \\
(\mathrm{RCT})\end{array}$ & $13-14$ & $\begin{array}{l}\text { CHX 1\%+ } \\
\text { thymol 1\% }\end{array}$ & placebo & $3 / 12$ & 85 & 14 & 2 & $\begin{array}{l}\text { 1st premolar- } \\
\text { 2nd molar/ } \\
\text { Approx. }\end{array}$ & $\begin{array}{l}2.38 \text { (test } \\
\text { quadrant) and } \\
2.67 \text { (placebo } \\
\text { quadrant) }\end{array}$ & FTP & $\begin{array}{l}\mathrm{E}+\mathrm{D} \\
\mathrm{B} / \mathrm{W} \text {, mean } \\
\text { difference in new } \\
\text { approx. lesions: }-0.21 \\
(95 \% \mathrm{CI}=-0.57-0.16) \\
\mathrm{NS}(\mathrm{p}>0.05)\end{array}$ & low \\
\hline $\begin{array}{l}\text { Rodrigues } \\
\text { [2008] } \\
\text { (QRCT) }\end{array}$ & $6-8$ & $\begin{array}{l}\text { CHX 1\%+ } \\
\text { thymol 1\% }\end{array}$ & placebo & $\begin{array}{l}\text { every } 2 \text { weeks for } \\
2.5 \text { months } \\
\text { (6 applications) }\end{array}$ & 57 & 0 & 1 & FPM/Occ. & $\begin{array}{l}\text { test and } \\
\text { control teeth } \\
\text { caries-free }\end{array}$ & $\begin{array}{l}\text { F water } \\
(0.7 \mathrm{ppm})\end{array}$ & $\begin{array}{l}E+D: N S \\
(p=0.20)\end{array}$ & high \\
\hline \multirow[t]{2}{*}{$\begin{array}{l}\text { Zhang } \\
\text { [2006] } \\
\text { (QRCT) }\end{array}$} & \multirow[t]{2}{*}{$6-7$} & \multirow[t]{2}{*}{ CHX 40\% } & \multirow[t]{2}{*}{ no tx } & $\begin{array}{l}\text { regimen } 1 \text { : } \\
0,6,12 \text { and } \\
18 \text { months }\end{array}$ & 305 & 15 & 2 & $\begin{array}{l}\text { FPM/pits } \\
\text { and fissures }\end{array}$ & $\begin{array}{l}\text { test and } \\
\text { control teeth } \\
\text { caries-free }\end{array}$ & $\begin{array}{l}\text { F water } \\
(0.25 \mathrm{ppm})\end{array}$ & $\begin{array}{l}\text { D: application } \\
\text { frequencies pooled } \\
\text { in analysis }\end{array}$ & \multirow[t]{2}{*}{ high } \\
\hline & & & & $\begin{array}{l}\text { regimen } 2 \text { : } \\
0,3,12 \text { and } \\
15 \text { months }\end{array}$ & & & & & & & $\begin{array}{l}\mathrm{PF}=25 \% \\
(95 \% \mathrm{CI}=1-49 \%) \\
\mathrm{S}(\mathrm{p}=0.04,1 \text {-sided })\end{array}$ & \\
\hline
\end{tabular}

$\mathrm{n}=$ Number of participants at baseline; $\mathrm{CHX}=$ chlorhexidine; $\mathrm{RCT}=$ randomised controlled trial; no tx = no treatment; $\mathrm{QRCT}=$ quasi-randomised controlled trial; FPM = first permanent molar; SPM = second permanent molar; Occ. = occlusal surface; Approx. = approximal surface; $\mathrm{D}=$ dentine; $\mathrm{E}+\mathrm{D}=$ enamel + dentine; $\mathrm{S}=$ statistically significant; $\mathrm{NS}=$ not statistically significant; $\mathrm{F}=$ fluoride; $\mathrm{FTP}=$ fluoride toothpaste; $\mathrm{B} / \mathrm{W}=\mathrm{bitewing}$ radiographs; $\mathrm{PF}=$ prevented fraction.

neity would be assessed in this manner. Parallel-group and splitmouth trials would be considered separately to take account of potential differences in effect due to study design. However, due to missing data and variation in the reporting of outcomes, this approach was not possible. Therefore, it was decided to present a narrative summary of the results in which parallel-group and split-mouth trials are considered separately. Heterogeneity was assessed informally by examination of the summary of results tables (tables 1 and 2).

\section{Results}

\section{Chlorhexidine Varnish Compared to Placebo or No Treatment in Permanent Teeth}

Six parallel-group trials assessed the effectiveness of chlorhexidine varnish compared to placebo or no treatment for preventing caries in permanent teeth and details of these trials are presented in table 1 . There was substantial variation between the trials in the concentration of chlorhexidine varnish used (1, 10 and 40\%), the baseline level of caries (range: 0-9.25 DMFS) and background fluoride exposure. The majority of the parallel-group trials assessed the effectiveness of chlorhexidine varnish at preventing caries on all surfaces of all teeth. Most of the trial participants were considered at moderate to high risk of developing dental caries. The duration of the trials ranged from 2 to 3 years, with the exception of 1 trial where the duration of the intervention was dependent on the treatment time with fixed orthodontic appliances (median duration 21 months) [Jenatschke et al., 2001]. One trial evaluated the effect 3 years after the termination of a 2-year trial [Baca et al., 2003]. None of the parallel-group trials included in the review reported a statistically significant reduction in caries in the chlorhexidine varnish groups compared to placebo or no treatment.

Four split-mouth trials assessed the effectiveness of chlorhexidine varnish for preventing caries and details of these trials are presented in table 2. Three of the trials evaluated 1\% chlorhexidine-thymol varnish [Bratthall et al., 1995; Haukali and Poulsen, 2003; Rodrigues et al., 
2008] and 1 trial evaluated 40\% chlorhexidine varnish [Zhang et al., 2006b]. Three of the 4 trials [Bratthall et al., 1995; Zhang et al., 2006b; Rodrigues et al., 2008] tested chlorhexidine varnish against placebo or no treatment using pairs of molars that were caries-free at baseline. One trial [Haukali and Poulsen, 2003] used quadrants of the mouth as the unit of randomisation and included teeth that were not all caries-free at baseline. Background exposure to fluoride was considered low in 1 trial [Zhang et al., 2006b]; participants of 1 trial had exposure to fluoridated water (0.7 ppm) [Rodrigues et al., 2008]; use of fluoride toothpaste was reported in 1 trial [Haukali and Poulsen, 2003], and background exposure to fluoride was not reported in the remaining trial [Bratthall et al., 1995]. There was variation in both the teeth and surfaces examined: 2 trials assessed the effect of chlorhexidine varnish for preventing caries on the occlusal surfaces of first permanent molars [Zhang et al. 2006b; Rodrigues et al., 2008], with 1 of these trials [Zhang et al. 2006b] also including the buccal and palatal pits. Bratthall et al. [1995] assessed the effect of chlorhexidine varnish on the occlusal surfaces of first and second permanent molars, and Haukali and Poulsen [2003] included the approximal surfaces of premolar and molar teeth in 2 quadrants of the mouth.

The results of the 4 split-mouth trials were conflicting: 2 of the trials, which had no-treatment control groups, reported results in favour of chlorhexidine varnish (1 and 40\%) [Bratthall et al., 1995; Zhang et al., 2006b]. The statistical significance of the results of the trial using the $40 \%$ concentration was borderline $(\mathrm{p}=0.04,1$-sided $)$ and the confidence interval was wide ( $95 \% \mathrm{CI}=1-49 \%)$ [Zhang et al., 2006b]. The 2 remaining split-mouth trials reported no significant difference in caries increment between the teeth that received $1 \%$ chlorhexidine varnish compared to the teeth that received placebo varnish [Haukali and Poulsen, 2003; Rodrigues et al., 2008].

\section{Chlorhexidine Varnish Compared to Placebo or No \\ Treatment in Primary Teeth}

Only 1 included trial evaluated the caries-preventive effect of chlorhexidine varnish in primary teeth [Du et al., 2006] (table 1). This double-blind cluster randomised placebo-controlled trial was conducted in China and involved 6-monthly applications of $40 \%$ chlorhexidine varnish in 4- to 5-year-old children with low background exposure to fluoride. Although the overall 2-year caries increment in primary molars was quite low, a statistically significant reduction in the caries increment in dentine was reported for children in the chlorhexidine varnish group compared to children in the placebo group (mean dmfs molar 1.0 versus $1.6, p=0.036$ ). The results suggested a $37.3 \%$ reduction in caries increment over 2 years.

Chlorhexidine Varnish Compared to Fluoride Varnish

One trial compared the caries-preventive effect of chlorhexidine varnish directly with that of fluoride varnish (table 1). In a single-blind, randomised controlled trial, Petersson et al. [2000] compared the effectiveness of 3-monthly $1 \%$ chlorhexidine-thymol varnish applications with 3 -monthly $0.1 \%$ fluoride varnish applications for preventing approximal caries in a group of 180 Swedish adolescents with background exposure to topical fluoride applications. The caries increment measured radiographically after 3 years was mostly in enamel and was slightly higher in the chlorhexidine varnish group, but the authors reported that the difference was not statistically significant (mean DMFS approximal 3.08 versus 2.81 respectively, no p value reported).

\section{Risk of Bias in Included Trials}

Sequence generation and allocation concealment were poorly reported in the majority of the included trials; only 4 of them reported sufficient information to assess the method of randomisation [Haukali and Poulsen, 2003; Du et al., 2006; Zhang et al., 2006b; Ersin et al., 2008]. One of the 4 was judged to be quasi-randomised and therefore at risk of selection bias because the method of randomisation, although systematic, was not considered to be truly random [Zhang et al., 2006b]. Personal communication with the author of another trial indicated that the trial was also quasi-randomised [Rodrigues et al., 2008]. Baseline imbalances in MS counts [Fennis-le et al., 1998] and caries levels [Forgie et al., 2000; Jenatschke et al., 2001], high or unexplained losses to follow-up [de Soet et al., 2002; Baca et al., 2003], lack of assessment of intraexaminer reliability [Petersson et al., 2000; de Soet et al., 2002] and small sample size [Jenatschke et al., 2001] reduced the quality of the evidence provided by the included trials.

\section{Adverse Effects and Acceptability of Treatment}

No adverse effects were reported in any of the included trials. Three trials reported that the chlorhexidine varnish (1 and 10\%) was well tolerated by the trial participants [Bratthall et al., 1995; Forgie et al., 2000; Rodrigues et al., 2008]. Two trials reported dropouts due to the taste of the varnish. Dropouts were minimal (2 participants) for one of these trials [Haukali and Poulsen, 2003] involving 13 -year-old children and $1 \%$ chlorhexidine-thymol 
varnish. The second trial [Du et al., 2006] reported that 13 participants aged $4-5$ years ( $4 \%$ of the participants at baseline) objected to the taste of the varnish ( $40 \%$ chlorhexidine) and refused to be examined.

\section{Discussion}

The results of the trials included in this review are conflicting, but in general, the evidence does not support the use of chlorhexidine varnish for preventing caries in children and adolescents. By restricting the included trials to randomised trials with blind outcome assessment, the intention was to focus the review on the highest-quality evidence available on the effectiveness of chlorhexidine varnish. However, despite this, the quality of the 12 included trials was disappointing, with only 4 being assessed as having a low risk of bias [Bratthall et al., 1995; Haukali and Poulsen, 2003; Du et al., 2006; Ersin et al., 2008]. Focusing our attention on the results of the 4 trials with a low risk of bias does not provide clarity as the results are still conflicting and the variation between the trials further confuses matters: 2 of the trials [Bratthall et al., 1995; Du et al., 2006] reported statistically significant results in favour of the chlorhexidine varnish but differed in their design, concentration of varnish used, application frequency, type of control group (no treatment in one trial and placebo in the other) and dentition to which the varnish was applied. The other 2 trials failed to find a significant caries-preventive effect for chlorhexidine varnish [Haukali and Poulsen, 2003; Ersin et al., 2008], and these trials differed in design, unit of analysis (quadrants versus individuals) and type of control (placebo versus dental health education). Evidence of the comparative effectiveness of chlorhexidine varnish and fluoride varnish comes from just 1 randomised trial [Petersson et al., 2000] and is equivocal.

The rationale for using chlorhexidine to prevent caries is based on its ability to effectively suppress MS. The duration of suppression of MS is variable and may be influenced by the chlorhexidine concentration of the varnish [Ribeiro et al., 2007]. Although suppression of MS has been shown to be more effective with higher-concentration varnishes such as $40 \%$ chlorhexidine [Schaeken et al., 1989; Schaeken et al., 1991; Attin et al., 2003], no pattern in relation to concentration and caries-preventive effect could be observed in this review. The frequency of application of the varnish may also influence the duration of MS suppression [Le and Schaeken, 1993], but among the trials that showed a significant effect, the frequency of application varied. The results of 2 trials sug- gest that any potential effect on caries fades 1-3 years after the last chlorhexidine varnish application [Baca et al., 2003; Zhang et al., 2006b].

The 3 trials that showed a significant effect for the use of chlorhexidine varnish were all conducted in developing countries: 2 in China [Du et al., 2006; Zhang et al., 2006b] and 1 in Thailand [Bratthall et al., 1995]. Exposure to fluoride and to preventive programmes can be considered low for the participants of the Chinese trials but is unknown for the trial conducted in Thailand. Chlorhexidine varnish may provide a benefit for children in developing countries, but the generalisablity of the results of these trials to the developed world can be questioned, particularly in view of the exposure of children in developed countries to fluoride from many sources.

There is a possibility of carry-over of the effect of chlorhexidine varnish from the test to the control side in the included split-mouth trials. The effect of such carryover would be to mask any variation in caries increment so that any differences between the test and control sides would be less likely to reach statistical significance. It is worth noting that 2 of the 3 trials that reported a statistically significant reduction in caries with chlorhexidine varnish application were split-mouth trials. Therefore a carry-over effect was not evident in the split-mouth trials included in this review.

In a narrative summary of results it is important to be cautious about drawing conclusions based on the results of individual trials because they may have been underpowered to detect, as statistically significant, a clinically relevant difference between the test and comparison groups. Of the 12 trials included in the review, only 4 reported that a formal method was used to determine the sample size [Forgie et al., 2000; Haukali and Poulsen, 2003; Du et al., 2006; Zhang et al., 2006b] and only 1 of these 4 trials was adequately powered at the end of the trial [Zhang et al., 2006b]. The other 3 trials were very slightly underpowered at follow-up due to higher than expected dropout of trial participants. It is not possible to make any judgement regarding the adequacy of the sample size for the remaining 8 trials.

The findings of this review are in agreement with the conclusion of the systematic review by Twetman [2004]. Of the 16 trials in his review, 8 failed to meet the inclusion criteria. Four of these excluded trials showed a statistically significant effect for chlorhexidine varnish treatment. Twetman concluded that the evidence for a cariespreventive effect of chlorhexidine varnish was inconclusive for children and adolescents with daily exposure to fluoride. 
The most recent systematic review of the effectiveness of chlorhexidine varnish [Zhang et al., 2006a] included 10 trials, 7 of which were also part of this review. The authors tentatively concluded that chlorhexidine varnish applied at 3- to 4-month intervals had a moderate cariespreventive effect but no influence when applied at longer intervals. The conclusion was based on the results of 4 split-mouth trials that showed a caries-inhibiting effect for chlorhexidine varnish applied at intervals of 3-4 months. Two of these 4 trials did not meet the inclusion criteria for the present review. The qualitative approach employed in the present review, combined with different criteria for inclusion of trials, may help to explain the difference in our conclusions.

Evidence for the effectiveness of chlorhexidine varnish for preventing caries in permanent and primary teeth of children and adolescents is generally lacking. Two trials judged to have a low risk of bias found a statistically significant effect for chlorhexidine varnish in permanent [Bratthall et al., 1995] and primary teeth [Du et al., 2006]; however as these trials were conducted in areas where background exposure to fluoride was either low or unreported, their applicability to children and adolescents in developed countries is questionable. Further well-conducted, adequately powered randomised trials with a focus on preschool children and children with erupting or newly erupted first permanent molars are required before its use as a caries-preventive agent can be advocated. Consideration should be given to using a high-concentration chlorhexidine varnish with an application frequency adequate to effectively suppress MS over the period of the trial. In the meantime, other cariespreventive agents with established effectiveness, such as fluoride varnish, should be used.

\section{Acknowledgements}

We are grateful to Prof. Denis O’Mullane for his expert guidance and invaluable feedback throughout the review process. Many thanks to Dr. Boika Rechel for her guidance and her feedback on the draft review. We would also like to thank Dr. Rosa Helena Grande and Prof. Ulrich Schlagenhauf for kindly providing us with additional information about their trials. This review was supported by the Health Research Board, Ireland (S/A013).

\section{References}

Ahovuo-Saloranta A, Hiiri A, Nordblad A, Mäkelä M, Worthington HV: Pit and fissure sealants for preventing dental decay in the permanent teeth of children and adolescents. Cochrane Database Syst Rev 2008; 4:CD001830

- Araujo AMPG, Naspitz GMCC, Chelotti A, Cai S: Effect of cervitec on mutans streptococci in plaque and on caries formation on occlusal fissures of erupting permanent molars. Caries Res 2002;36:373-376.

-Attin R, Tuna A, Attin T, Brunner E, Noack MJ: Efficacy of differently concentrated chlorhexidine varnishes in decreasing mutans streptococci and lactobacilli counts. Arch Oral Biol 2003;48:503-509.

- Baca P, Junco P, Bravo M, Baca AP, Muñoz MJ: Caries incidence in permanent first molars after discontinuation of a schoolbased chlorhexidine-thymol varnish program. Community Dent Oral Epidemiol 2003:31:179-183.

- Baca P, Muñoz MJ, Bravo M, Junco P, Baca AP: Effectiveness of chlorhexidine-thymol varnish for caries reduction in permanent first molars of 6-to 7-year-old children: 24-month clinical trial. Community Dent Oral Epidemiol 2002;30:363-368.
Baca P, Muñoz MJ, Bravo M, Junco P, Baca AP. Effectiveness of chlorhexidine-thymol varnish in preventing caries lesions in primary molars. ASDC J Dent Child 2004;71:61-65.

- Balanyk TE, Sandham HJ: Development of sustained-release antimicrobial dental varnishes effective against Streptococcus mutans in vitro. J Dent Res 1985;64:1356-1360.

Bonesvoll P, Lökken P, Rölla G, Paus PN: Retention of chlorhexidine in the human oral cavity after mouthrinses. Arch Oral Biol 1974; 19:209-212

Bratthall D, Serinirach R, Rapisuwon S, Kuratana M, Luangjarmekorn V, Luksila K, Chaipanich P: A study into the prevention of fissure caries using an antimicrobial varnish. Int Dent J 1995;45:245-254

De Amorim RG, Leal SC, Bezerra ACB, De Amorim FPLG, De Toledo OA: Association of chlorhexidine and fluoride for plaque control and white spot lesion remineralization in primary dentition. Int $\mathrm{J}$ Paediatr Dent 2008:18:446-451.

De Soet JJ, Gruythuysen RJM, Bosch JA, van Amerongen WE: The effect of 6-monthly application of $40 \%$ chlorhexidine varnish on the microflora and dental caries incidence in a population of children in Surinam. Caries Res 2002;36:449-455.
Du MQ, Tai BJ, Jiang H, Lo ECM, Fan MW, Bian Z: A two-year randomized clinical trial of chlorhexidine varnish on dental caries in Chinese preschool children. J Dent Res 2006; 85:557-559.

Emilson CG: Effect of chlorhexidine gel treatment on Streptococcus mutans population in human saliva and dental plaque. J Dent Res 1981;89:239-246.

Emilson CG: Potential efficacy of chlorhexidine against mutans streptococci and human dental caries. J Dent Res 1994;73:682-691.

- Ersin NK, Eden E, Eronat N, Totu FI, Ates M: Effectiveness of 2-year application of schoolbased chlorhexidine varnish, sodium fluoride gel, and dental health education programsinhigh-risk adolescents. Quintessence Int 2008;39:e45-e51.

Fennis-le YL, Verdonschot EH, Burgersdijk RC, König KG, van't Hof MA: Effect of 6-monthly applications of chlorhexidine varnish on incidence of occlusal caries in permanent molars: a 3-year study. J Dent 1998;26:233238.

Forgie AH, Paterson M, Pine CM, Pitts NB, Nugent ZJ: A randomised controlled trial of the caries-preventive efficacy of a chlorhexidine-containing varnish in high-caries-risk adolescents. Caries Res 2000;34:432-439. 
Haukali G, Poulsen S: Effect of a varnish containing chlorhexidine and thymol (Cervitec) on approximal caries in 13- to 16-year-old schoolchildren in a low-caries area. Caries Res 2003;37:185-189.

Higgins JPT, Deeks JJ: Selecting trials and collecting data; in Higgins JPT, Altman DG (eds): Cochrane Handbook for Systematic Reviews of Interventions. Version 5.0.2 (updated 2009). London, Cochrane Collaboration, 2009, chapt 7.

- Jenatschke F, Elsenberger E, Welte HD, Schlagenhauf U: Influence of repeated chlorhexidine varnish applications on mutans streptococci counts and caries increment in patients treated with fixed orthodontic appliances. J Orofac Orthop 2001;62:36-45.

Kay EJ, Locker D: Is dental health education effective? A systematic review of current evidence. Community Dent Oral Epidemiol 1996;24:231-235.

Le YL, Schaeken MJM: Effect of single and repeated application of chlorhexidine varnish on mutans streptococci in plaque from fissures of premolar and molar teeth. Caries Res 1993;27:303-306.

Loesche WJ: Role of Streptococcus mutans in human dental decay. Microbiol Rev 1986;50: 353-380.

Madlena M, Vitalyos G, Marton S, Nagy G: Effect of chlorhexidine varnish on bacterial levels in plaque and saliva during orthodontic treatment. J Clin Dent 2000;11:42-46.

Marinho V, Higgins J, Logan S, Sheiham A: Fluoride varnishes for preventing dental caries in children and adolescents: Cochrane Database Syst Rev 2002a;1:CD002279.

Marinho V, Higgins J, Logan S, Sheiham A: Fluoride gels for preventing dental caries in children and adolescents. Cochrane Database Syst Rev 2002b;1:CD002280.

Marinho V, Higgins J, Logan S, Sheiham A: Fluoride toothpastes for preventing dental caries in children and adolescents. Cochrane Database Syst Rev 2003a;1:CD002278.
Marinho V, Higgins J, Logan S, Sheiham A: Fluoride mouthrinses for preventing dental caries in children and adolescents. Cochrane Database Syst Rev 2003b;3:CD002284.

Mejàre I, Lingström P, Petersson LG, Holm AK Twetman S, Källestål C, Nordenram G, Lagerlöf F, Söder B, Norlund A, Axelsson S, Dahlgren H: Caries-preventive effect of fissure sealants: a systematic review. Acta Odontol Scand 2003;61:321-330.

Dogaard B, Larsson E, Glans R, Henriksson T, Birkhed D: Antimicrobial effect of a chlorhexidine-thymol varnish (Cervitec) in orthodontic patients: a prospective, randomized clinical trial. J Orofac Orthop 1997;58:206-213.

Petersen PE: The World Oral Health Report 2003:Continuous improvement of oral health in the 21st century - the approach of the WHO Global Oral Health Programme. Community Dent Oral Epidemiol 2003;31: $3-23$.

Petersson LG, Magnusson K, Andersson $\mathrm{H}$ Almquist B, Twetman S: Effect of quarterly treatments with a chlorhexidine and a fluoride varnish on approximal caries in cariessusceptible teenagers: a 3-year clinical study. Caries Res 2000;34:140-143.

Plotzitza B, Kneist S, Berger J, Hetzer G: Efficacy of chlorhexidine varnish applications in the prevention of early childhood caries. Eur J Paediatr Dent 2005;6:149-154.

Ribeiro LG, Hashizume LN, Maltz M: The effect of different formulations of chlorhexidine in reducing levels of mutans streptococci in the oral cavity: a systematic review of the litera ture. J Dent 2007;35:359-370.

-Rodrigues CRMD, Marquezan M, Barroso LP, Grande RHM, Myaki SI, Kabakura V, Miyamura A: Effect of chlorhexidine-thymol varnish on caries lesion development in first permanent molars. J Clin Dent 2008;19:1821.

Rölla G, Löe H, Rindom Schiött C: Retention of chlorhexidine in the human oral cavity. Arch Oral Biol 1971;16:1109-1116.

-Schaeken MJ, Schouten MJ, Van Den Kieboom CW, Van Der Hoeven JS: Influence of contact time and concentration of chlorhexidine varnish on mutans streptococci in interproximal dental plaque. Caries Res 1991;25 292-295.
Schaeken MJ, van der Hoeven JS, Hendriks JC: Effects of varnishes containing chlorhexidine on the human dental plaque flora. J Dent Res 1989;68:1786-1789.

Skold-Larsson K, Fornell AC, Lussi A, Twetman S: Effect of topical applications of a chlorhexidine/thymol-containing varnish on fissure caries assessed by laser fluorescence. Acta Odontol Scand 2004;62:339-342.

$\checkmark$ Splieth C, Steffen H, Rosin M, Welk A: Caries prevention with chlorhexidine-thymol varnish in high-risk schoolchildren. Community Dent Oral Epidemiol 2000;28:419-423.

Twetman S: Antimicrobials in future caries control? A review with special reference to chlorhexidine treatment. Caries Res 2004; 38:223-229.

- Twetman S, Petersson LG: Interdental caries incidence and progression in relation to mutans streptococci suppression after chlorhexidine-thymol varnish treatments in schoolchildren. Acta Odontol Scand 1999; 57:144-148

Van Houte J: Bacterial specificity in the etiology of dental caries. Int Dent J 1980;30:305-320.

-Vanobbergen J, Declerck D, Mwalili S, Martens L: The effectiveness of a 6-year oral health education programme for primary schoolchildren. Community Dent Oral Epidemiol 2004;32:173-182.

-Van Rijkom HM, Truin GJ, van't Hof MA: A meta-analysis of clinical studies on the caries-inhibiting effect of chlorhexidine treatment. J Dent Res 1996;75:790-795.

Zhang Q, van Palenstein Helderman WH, van't Hof MA, Truin GJ: Chlorhexidine varnish for preventing dental caries in children, adolescents and young adults: a systematic review. Eur J Oral Sci 2006a;114:449-455.

Zhang Q, van't Hof MA, Truin GJ, Bronkhorst EM, van Palenstein Helderman WH: Cariesinhibiting effect of chlorhexidine varnish in pits and fissures. J Dent Res 2006b;85:469474. 